UDC 343

DOI https://doi.org/10.32782/2524-0374/2019-5/53

\title{
SMUGGLING IN UKRAINE: PROBLEMS OF COUNTERACTION AND DIRECTIONS OF THEIR IMPROVEMENT
}

\author{
КОНТРАБАНДА В УКРАЇНІ: \\ ПРОБЛЕМИ ПРОТИДІЇ ТА НАПРЯМИ ЇХ УДОСКОНАЛЕННЯ
}

\author{
Didkivska H.V., Candidate of Law, Associate Professor, \\ Associate Professor of the Department of Criminal Law and Criminology \\ State Fiscal Service of Ukraine \\ Matkevych Y.Y., Graduate Student \\ of the Department of Criminal Law and Criminology \\ State Fiscal Service of Ukraine
}

The article explores the anticriminogenic importance of measures aimed at eliminating the sharp material stratification of society, material support for low-income citizens, limiting the negative consequences of unemployment as inevitable satellites of social and economic reforms. Positive processes in the political, spiritual and legal spheres of public administration are also indicated as having anti-crime significance, and they affect almost all types, groups, types of causes, conditions and other determinants of crime. The complex nature of crime prevention, and in particular smuggling and trafficking of sub-excise goods, is clearly evident at the social level, as different measures are integrated. Shortcomings in the work of the judiciary, such as the inadequate assessment of the court and the ratio of crime to leniency of punishment for foreign smugglers, were highlighted, as well as the lack of normative material for international cooperation. Ukraine has not yet concluded relevant agreements on legal assistance in civil, family and criminal proceedings with some States. It was noted that smuggling of certain items, such as the illicit export of cultural property, was not a crime under all national legislation. The prerequisites for the development of smuggling activities in the border territories of Ukraine have been identified, such as 1) the advantageous geographical and transport position of the territory of the State; 2) functional failure of the State Border Service of Ukraine to ensure control over the crossing of the state border along its entire length line; 3) excessive number of control procedures during customs clearance of products, goods, material assets and the like; 4) high level of corruption and bureaucracy of public officials; 5) criminalization of state authorities, economic entities and society as a whole; 6 ) high rates of export and import duties; 7) low efficiency of law enforcement and judicial bodies; 8) psychological incentives and desire of entrepreneurs to get extra profits; 9 ) imperfections of the system of customs-tariff regulation of export-import operations; 10) the practice of lobbying interests in state authorities by representatives of large business is common; 11) mainly low level of income and poverty of the population living in the border areas; 12) opacity of export-import operations; 13) bad faith of individual employees of the State Border Service of Ukraine and the State Fiscal Service of Ukraine; 14) transnational nature of development of criminal structures.

Key words: crime, smuggling, counteraction, crime, benefit, shadow economy.

У статті досліджується антикриміногенне значення заходів, спрямованих на усунення різкого матеріального розшарування суспільства, матеріальної підтримки малозабезпечених громадян, обмеження негативних наслідків безробіття як неминучих супутників соціально-економічних реформ. Позитивні процеси в політичній, духовній і правовій сфрерах державного управління також мають антикриміногенне значення, вони впливають практично на всі види, групи, різновиди причин, умов та інших детермінантів злочинності. Комплексний характер попередження злочинності, зокрема контрабанди та незаконного обігу підакцизних товарів, чітко проявляється саме на соціальному рівні, оскільки тут інтегруються різні за своїм змістом заходи. Виокремлено недоліки роботи судових органів, такі як: неадекватна оцінка суду і співвідношення вчиненого злочину та м'якості покарання для іноземних громадян, котрі вчинили контрабанду, а також звернено увагу на недостатність нормативного матеріалу для міжнародної співпраці. 3 деякими державами Україна ще не уклала відповідних угод про надання правової допомоги у цивільних, сімейних і кримінальних провадженнях. Зазначено, що контрабанда деяких предметів, наприклад, незаконне вивезення культурних цінностей, не всіма національними законодавствами визнається злочином. Виокремлено передумови розвитку контрабандної діяльності на прикордонних територіях України, такі як: 1) вигідне географрічне і транспортне положення території держави; 2) функціональна неспроможність Державної прикордонної служби України забезпечити контроль за перетином державного кордону на всій лінії його протяжності; 3) надмірна кількість контрольних процедур під час митного оформлення продукції, товарів, матеріальних цінностей тощо; 4) високий рівень корумпованості та бюрократизму державних чиновників; 5) криміналізація органів державної влади, суб'єктів господарювання та суспільства загалом; 6) високі ставки експортних та імпортних мит; 7) низька ефективність роботи органів правоохоронної та судової систем; 8) психологічні стимули та бажання підприємців до отримання надприбутків; 9) недосконалість системи митно-тарифного регулювання експортно-імпортних операцій; 10) поширена практика лобіювання інтересів в органах державної влади представниками великого бізнесу; 11) переважно низький рівень доходів і бідність населення, яке проживає на прикордонних територіях; 12) непрозорість здійснення експортно-імпортних операцій; 13) недобросовісність окремих працівників Державної прикордонної служби України та Державної фіскальної служби України; 14) транснаціональний характер розвитку криміногенних структур.

Ключові слова: злочин, контрабанда, протидія, злочинність, користь, тіньова економіка.

Statement of a problem. The problem of smuggling into Ukraine on the side of corruption has become unprecedented and the fight against this negative phenomenon is one of the priority tasks of the State in protecting its economic interests. First of all, smuggling in its essence causes great damage to the financial and credit system in the state, affects foreign economic activity, fuel and energy sphere, and also caused the failure to receive a dozen billion UAH in the budget of the country. Due to the fact that a large part of export-imported goods flows in Ukraine are of smuggling origin, the state of development of the domestic economy is deteriorating, the domestic market is destabilized, as illegal import of foreign goods reduces the demand for Ukrainian non-competitive products, causing damage to the domestic commodity producer.

Analysis of the last researches and publications. Smuggling as a crime was considered in the research of domestic and foreign scientists: S.A. Hadyboeva, V.O. Vladimirova, Yu.G. Kislovsky, M.P. Karpushina, O.M. Omelchuk, O.V. Protsyuk, V.V. Silenko, Yu.I. Suchkova and others. However, special attention needs to be paid to addressing the problem of improving the effectiveness of combating drug smuggling by improving criminal and criminal justice measures.

Purpose of scientific research is a solution to the issues of further improvement of criminal and criminological measures in the field of combating drug smuggling. 
Statement of the main material. In addition, the results of such criminal activities negatively affect public relations in the field of protection of the life and health of citizens (smuggling of weapons and ammunition, nuclear materials and narcotic substances,) and deprive them of their right to use cultural values and the historical heritage of our State. This gives reason to argue that smuggling should be considered one of the most dangerous threats to Ukraine's national security at the present stage.

In the social sphere, measures aimed at eliminating the sharp material stratification of society, material support for low-income citizens, limiting the negative consequences of unemployment, etc., are important in the area of crime. As inevitable satellites of socio-economic reforms. Positive processes in the political, spiritual and legal spheres of public administration are also of anti-crime importance, they affect almost all kinds, groups, varieties of causes, conditions and other determinants of crime. The complex nature of crime prevention, and in particular smuggling and trafficking of sub-excise goods, is clearly evident at the social level, as it integrates different measures (economic, political, social, cultural and educational, legal, organizational, etc.) [3, p. 4-5].

Criminal and criminal procedural legislation contains certain shortcomings with regard to the type of offence under investigation. It is long overdue to give the status of law enforcement agencies and the right to carry out operational and search activities to certain units of customs authorities (anti-smuggling and own security departments), which, in our view, will significantly increase the level of fight against corruption and smuggling. This situation has an unsatisfactory impact on the fight against smuggling and corruption in customs authorities. Domestic legislation does not give the right to engage in operational and search activities to units of the Fiscal Service of Ukraine that combat smuggling, so when implementing complex operational and search activities of an international nature, the relevant intelligence and operational units of customs authorities of other states even refuse to provide the necessary information to the Ukrainian side $[8$, p. 396]. This significantly reduces the effectiveness of joint action and negatively affects the effectiveness of combating smuggling in general.

Without having an opportunity to carry out such activity, customs authorities spend time for the procedure of attraction to participation in business of specially authorized divisions of the SSU or Organized Crime Control Department of the Ministry of Internal Affairs of Ukraine, and loss of time reduces the probability of establishment of all circumstances which belong to a proof subject of criminal case. In addition, the Criminal Procedure Code of Ukraine does not provide for the provision of instructions by the bodies of inquiry to each other. In accordance with paragraph 2 of Part 1 of Article 7 of the Law of Ukraine "On Operational and Search Activities", units carrying out operational and search activities are obliged to comply only with written instructions of the investigator, instructions of the prosecutor and court decisions, requests of authorized state bodies, institutions and organizations to carry out operational and search activities [4].

It should be noted that among the shortcomings in the work of the judiciary is the inadequate assessment of the court and the ratio of the crime committed to the leniency of punishment for foreign nationals who have committed smuggling. Unfortunately, our content analysis of criminal proceedings did not reveal a single case of actual deprivation of liberty.

Among the problems that exist in this area is the lack of normative material for international cooperation. For example, Ukraine has not yet concluded relevant agreements on legal assistance in civil, family and criminal proceedings with some States. It should be noted, however, that the smuggling of certain items, such as the illegal export of cultural property, is not a crime under all national legislation. Therefore, there is often a situation where countries do not recognize such actions as criminal, do not agree to cooperate in solving these crimes, even if they have signed the relevant agreements [5].

The Convention on the Means of Prohibiting and Preventing the Illicit Import, Export and Transfer of Ownership of Cultural Property, of 14 November 1970, provides for measures for the return of stolen or illegally exported cultural property in cases where such acts have violated the domestic laws of the States parties to those conventions. The basis for return is the existence of criminal proceedings, and the procedure for return is provided for by existing international procedures and is implemented through State-authorized bodies (Ministry of Culture and Tourism, Ministry of Foreign Affairs, etc.). The problem is that not all States have acceded to, ratified and implemented the above-mentioned conventions. One of the options is the conclusion of bilateral agreements on this sphere of international relations.

Even with the necessary international agreements, the problem arises of Governments failing to meet mutual obligations for various reasons. Thus, according to customs officials, operational units of customs services of other states do not always inform SFS of Ukraine about the conduct of multi-way international operations to suppress smuggling, which significantly limits the possibilities of SFS of Ukraine to participate in international cooperation to combat smuggling [2].

According to articles 563-567 of the Customs Code of Ukraine, in the exercise of their functions, the customs authorities of Ukraine may interact with customs and other authorities of foreign States and with international organizations. Harmonization of customs authorities is particularly necessary at the inter-State level. It is only through joint efforts that the effectiveness of countering smuggling can be achieved. International cooperation takes various levels and forms.

Among the main prerequisites for the development of smuggling activities in the border areas of Ukraine, it is useful to highlight the following:

1) advantageous geographical and transport position of the territory of the state;

2) functional failure of the State Border Service of Ukraine to ensure control over the crossing of the state border along its entire length line;

3 ) excessive number of control procedures during customs clearance of products, goods, material assets and the like;

4) high level of corruption and bureaucracy of public officials;

5) criminalization of state authorities, economic entities and society as a whole;

6) high rates of export and import duties;

7) low efficiency of law enforcement and judicial bodies;

8) psychological incentives and desire of entrepreneurs to get extra profits;

9) imperfections of the system of customs-tariff regulation of export-import operations;

10) the practice of lobbying interests in state authorities by representatives of large business is common;

11) mainly low level of income and poverty of the population living in the border areas;

12) opacity of export-import operations;

13) bad faith of individual employees of the State Border Service of Ukraine and the State Fiscal Service of Ukraine;

14) transnational nature of development of criminal structures $[1$, p. 60].

In turn, Yu. Turchin among basic reasons of smuggling considers disorder and vulnerability of frontier on the majority of its sections. The greatest difficulties connected with identification of the illicit flows arising in a zone of border which between Ukraine and neighboring states is up to the end uncoordinated. The most widespread this problem on border sections with the states neighbors members of the CIS. It the determining factor when choosing such way of commission of smuggling, as movement of goods through customs border of 
Ukraine out of customs control. Smugglers in this case use for achievement of the purpose detours [7, p. 55].

The geographical location of Ukraine, passing through its territory of the main trunk ways connecting the East and the West and also lack of an effective control system abroad on all line of its extent, especially in the conditions of wartime increase risks of adjustment of illicit flows of goods, products, material values. It not only complicates development of effective organizational and economic mechanisms of fight against smuggling in boundary territories of Ukraine, but also stirs up activity of criminal groupings and activates development of shadow processes in economy.

Boundary territories as the place of direct development of the illicit relations are characterized by insufficient efficiency of use of the natural and resource potential which is available for them and advantages of geographically territorial placement. It is caused by the insufficient level of investment attractiveness of border territories, backwardness of their financial, market, social, household infrastructure, administrative crisis and deterioration in the human capital that is caused by both internal, and external labor migration. For simplification of processes of structurization of risks of emergence of smuggling in a border area and developments of effective organizational and economic tools on fight against it systematization of border territories on the nature of their development is reasonable:

1) the first category includes territories within which there is a developed network of specialized crossing points across the state border, customs posts, road and transport and logistics infrastructure, stimulates the processes of social and economic development of border territories, is a source of employment of the local population and provides revenues to the local budget. Such border areas are characterized by relative development, a lot of functionality and a quality of life of the population, and they live on them;

2) The second category is characterized by the absence of customs and access infrastructure across the state border on their territory, constrains the pace of socio-economic, innovative and cultural development of these border territories. However, the latter are characterized by the development of road traffic, the conduct of non-agricultural economic activities and the existence of horizontal-vertical links between economic entities;

3 ) the third category is territories characterized mainly by peripheral and mono-functional type of development, lack of infrastructure, low level of their mutual integration and cooperation, underdevelopment of regional economic mechanism. This makes it difficult to properly monitor the crossing of the State border along its length line [1, p. 61].

The need to improve the activities of the SFS of Ukraine requires better training of the employees of this service, which will allow them to perform their duties better. As of 2016, persons with higher education were 91\% among customs officials, including about $15 \%$ with legal education and $23 \%$ with economic education. Thus, in 2015, the Court of Appeal of Odessa region summarized the practice of considering cases of smuggling and violation of customs rules from 2011 to 2015 , concluding according to the results of the synthesis that there are a significant number of errors in the conduct of inquiry and pre-trial investigation on this category of crimes [6, p. 45].

Conclusions. So, despite the fact that already quite high indicators on higher education of employees of customs and authorities of SFS of Ukraine, in general, however, taking into account peculiarities of customs business, there is a need for a much higher percentage of specialists with higher legal education. This is especially true for employees of the anti-smuggling service and customs guards, internal security units, because in cases of smuggling, employees of the SFS of Ukraine are quite often mistaken, sometimes even making it impossible to further investigate the crime by investigative bodies.

\section{REFERENCES}

1. Волошин В.І. Боротьба з контрабандою на прикордонних територіях як інструмент зміцнення економічної безпеки держави. Соц.-ек. проблеми сучас. періоду України. 2014. Вип. 4 (108). С. 56-64.

2. Гайворонський Є.П. Контрабанда культурних цінностей: кримінологічна характеристика, детермінація та запобігання : дис ... канд. юрид. наук : 12.00.08. Харків, 2009. 212 с.

3. Марко С.І., Турчин Ю.Б. Попередження контрабанди та незаконного обігу підакцизних товарів заходами економічного характеру. Науковий вісник Львівського державного університету внутрішніх справ. Серія юридична. 2011. Вип. 1 (2). 384 с.

4. Про оперативно-розшукову діяльність : Закон України від 18 лютого 1992 р. № 2135-XII. Відомості Верховної Ради України. 1992. № 22. Ст. 303.

5. Пшеничний І.В. Організована транснаціональна злочинність і роль правоохоронних органів у протидії їй : дис. ... канд. юрид. Наук : 12.00 .08 . Київ, 2000. 220 с.

6. Тараненко О.М. Сучасні завдання прокуратури щодо виконання постанови Кабінету Міністрів України від 1 квітня 2005 року «Про затвердження державної програми «Контрабанді - СТОП» на 2005-2006 роки». Митна справа. 2007. № 3. С. 44-46.

7. Турчин Ю.Б. Особливості детермінації контрабанди підакцизних товарів. Митна справа. 2011. № 1 (73). С. $49-56$.

8. Щербань В.А. Організація боротьби з контрабандою наркотичних засобів, психотропних речовин та прекурсорів. Боротьба з контрабандою: проблеми та шляхи їх вирішення. Київ, 1998. Т. 10. С. 390-397. 